\title{
Antigenic variants of infectious hematopoietic necrosis virus and implications for vaccine development
}

\author{
S. E. LaPatra, K. A. Lauda, G. R. Jones \\ Clear Springs Foods, Inc., PO Box 712, Buhl, Idaho 83316, USA
}

\begin{abstract}
Two monoclonal antibodies and 2 polyclonal antisera were used in cross-neutralization tests of 106 isolates of infectious hematopoietic necrosis virus (IHNV) obtained from acutely infected rainbow trout Oncorhynchus mykiss at 4 locations in a 12 mile section of the Snake River, Idaho, USA, during 1990 to 1992. Ten antigenic groups exhibiting different neutralization profiles were identified. Approximately $91 \%$ of these isolates fell into 3 of the groups. Each location exhibited a range of antigenic variants from 1 to 7 . Prevalence of isolates within a group also varied. The frequency of different antigenic groups and prevalence of isolates within each group differed over time. Virulence comparisons using representative isolates from 7 of the antigenic groups to challenge rainbow trout at 2 different mean body weights resulted in average cumulative mortalities that ranged from 14 to $92 \%$. Passive immunization of rainbow trout with convalescent (immune) serum from fish exposed to 1 antigenic variant provided significant protection after challenge with representative isolates from other variant groups. Relative protection of fish injected with immune serum compared to normal serum ranged from 91 to $100 \%$. The results indicated that neutralizing activity produced against 1 antigenic variant of IHNV would cross-protect against other antigenic variants. A vaccine against a single type of IHNV may be efficacious against all IHNV strains.
\end{abstract}

KEY WORDS: IHNV - Antigenic variants - Rainbow trout Vaccine development

\section{INTRODUCTION}

Infectious hematopoietic necrosis virus (IHNV) is a rhabdovirus causing epizootics among wild (Williams \& Amend 1976) and hatchery-reared salmonid fish (Groberg \& Fryer 1983). This virus impacts cultured salmon and trout worldwide and is the most important viral pathogen affecting salmonid fish in North America (Wolf 1988). The disease caused by the virus was first reported in the 1950's in hatchery-reared sockeye salmon Oncorhynchus nerka fry in Washington and Oregon, USA (Rucker et al. 1953, Wingfield et al. 1969). Similar epizootics were observed in the 1960's among chinook salmon Oncorhynchus tshawytscha fry in hatcheries on the Sacramento River in California, USA, and in rainbow trout Oncorhynchus mykiss in British Columbia, Canada (Wingfield \& Chan 1970, Amend et al. 1969). Viral isolates from these epizootics were compared by electron microscopy, cell culture pathogenicity, and cross-neutralization using polyclonal rabbit antisera, and the results suggested the viruses were the same (Amend \& Chambers 1970); however, differences in neutralization kinetics were observed that indicated strain variation (McCain et al. 1971).

Differences among isolates in the molecular weights of their glycoprotein (G) and/or nucleocapsid protein (N) have been reported for IHNV (Leong et al. 1981). These differences have allowed separation of viral isolates into 5 electropherotypes (Hsu et al. 1986). These types generally correlated with the geographic area from which they were obtained. Winton et al. (1988) separated $12 \mathrm{IHNV}$ isolates into 4 groups by use of 3 neutralizing monoclonal antibodies reacting with the $\mathrm{G}$ protein of 3 different electropherotypes. The isolates within each antigenic group were generally related by 
geographic area. Ristow \& Arnzen de Avila (1991) produced monoclonal antibodies against the $G$ and $N$ proteins of different electropherotypes of IHNV and detected greater serological variation among the $G$ proteins of selected isolates than among the $\mathrm{N}$ proteins. However, Engelking et al. (1991) reported that a serum neutralization test that used 4 polyclonal rabbit antisera reacted with 10 distinct IHNV isolates representing all 5 biochemically defined types from different geographic locations failed to show any serotypic differences

The IHNV G protein has been shown to be the only viral protein capable of eliciting neutralizing antibodies in rabbits and stimulating protective immunity in young fish (Engelking \& Leong 1989). However, in recent years there appears to be evidence for increasing serological variation among IHNV isolates, with distinct neutralizing profiles (Winton et al. 1988, Groberg et al. 1990, LaPatra et al. 1991a, Ristow \& Arnzen de Avila 1991). Whether some of these variants are indeed unique serotypes has not been thoroughly investigated and this information will be essential for development of an effective vaccine. Additionally, knowledge of antigenic variation among isolates of IHNV is important for epizootiological studies, development of accurate diagnostic tests, fish health management, and understanding the biology of the virus.

It has been previously reported that heterogeneity exists in the serum neutralization profiles among isolates of IHNV from different years and locations in the Hagerman Valley, Idaho, USA (LaPatra et al. 1991a). A potentially unique strain that was not neutralized by a monospecific polyclonal antibody against the $G$ protein was also described (Groberg et al. 1990). Serum neutralization profiles using 6 monoclonal and 3 polyclonal antisera reacting with the $G$ protein resulted in 3 predominant patterns that correlated with virulence in rainbow trout. This study reports the establishment of a standardized serum neutralization monitoring program that can be used to compare temporal, geographic and virulence differences among antigenic variants of IHNV and to estimate the importance of these serological differences for vaccine development.

\section{MATERIALS AND METHODS}

Cell lines. The epithelioma papulosum cyprini (EPC) cell line from common carp Cyprinus carpio (Fijan et al. 1983) was used for the isolation, propagation, quantitation, and identification of YHNV isolates, Cells were propagated in minimum essential medium (MEM) supplemented with 10\% fetal bovine serum (FBS; Sigma Chemical Company, St. Louis, MO, USA, MEM-10), Lglutamine $(10 \mathrm{mM})$, penicillin (10 IU $\left.\mathrm{ml}^{-1}\right)$, and strep- tomycin (50 $\mathrm{hg} \mathrm{ml}^{-1}$ ) (all from GIBCO Laboratories, Grand Island, NY, USA) and buffered (to pH 7.5) with $7.5 \%$ sodium bicarbonate (GIBCO) and $1 \mathrm{M}$ Hepes (Sigma). For routine cell propagation the EPC line was incubated at $25^{\circ} \mathrm{C}$. Isolates of IHNV for antigenic and virulence comparisons were grown in EPC cells at $18^{\circ} \mathrm{C}$ in MEM-2 $(2 \%$ FBS $)$ and stored at $-80^{\circ} \mathrm{C}$

Virus isolates. Isolates of IHNV were recovered from acutely infected juvenile rainbow trout during routine examinations of hatchery-reared fish conducted from 1990 to 1992 in the Hagerman Valley. Specimens for virus isolation were collected when mortality increased above 200 fish $\mathrm{d}^{-1}$. Viruses were isolated and identified by methods previously described (Amos 1985). All isolates were passed twice in EPC cells prior to testing.

Alpha neutralization tests. Four neutralizing antibody preparations $(2$ monoclonal and 2 polyclonal antisera) were used in cross-neutralization analyses. One monoclonal antibody (RB/B5) was obtained from J. L. Fryer, Oregon State University, Corvallis, Oregon, and a second (1H8) was obtained from J. R. Winton, National Fisheries Research Center, Seattle, Washington. Two polyclonal antisera made in rabbits were supplied by Jo-Ann C. Leong and H. Mark Engelking, Oregon State University, one against whole virus (Anti-IHNV) and a second antiserum made against purified IHNV glycoprotein (Anti-G; monospecific polyclonal antibody) of the Round Butte strain of IHNV. Production and characterization of these antibodies has been previously described (Winton et al. 1988, Engelking et al. 1991, Huang et al. 1994).

Neutralizing antibody titers were determined using a modification of the alpha procedure of Rovozzo \& Burke (1973). Undiluted hybridoma fluids, or polyclonal antibodies diluted 1:25 in MEM-2, were reacted with equal volumes of virus dilutions of each isolate prepared in 48-well microplates (GIBCO). After $60 \mathrm{~min}$ of incubation at $18^{\circ} \mathrm{C}$ with continuous rocking, the serum-virus mixtures were titered by plaque assay using monolayers of EPC cells. The $\log _{10}$ neutralization index (LNI) was determined as the difference in exponents of the $\log _{10}$ plaque assay titer between the virus dilutions incubated with and without antibody. A reaction in which the LNI exceeded 1.7 was scored as positive for neutralization. To prevent variation in virus or antibody stocks from affecting the results, groups of 24 isolates were examined by cross-neutralization tests performed over $2 \mathrm{~d}$ with the same pool of reagents, in cell cultures that were the same age, $\mathrm{pH}$, and degree of confluency. Additionally, 3 isolates that exhibited different neutralization profiles were included in each test as controls. The results were only tabulated if the control isolates reacted with each antibody as predicted. Isolates that did not test positive in serum neu- 
tralization tests were tested using an indirect fluorescent antibody test (IFAT) (LaPatra et al. 1989).

Virus challenge and passive immunization of fish. Virulence comparisons were done using 2 different sizes of fish (mean weights 1.2 and $4.8 \mathrm{~g}$ ) challenged with representative isolates from 7 of the antigenic groups. Two passive immunization studies were done to determine if serum produced against one antigenic variant of IHNV could confer protection in fish against challenge with other antigenic variants. In the first study, rainbow trout (mean weight, $2.9 \mathrm{~g}$ ) were injected with $50 \mu \mathrm{l}$ of fish immune serum (titer 640) produced against IHNV isolate 220-90 (neutralization profile group II) and challenged after $24 \mathrm{~h}$ with representative isolates from 6 of the other antigenic groups. In a second study, smaller fish (mean weight $1 \mathrm{~g}$ ) were passively immunized and then challenged with the homologous strain (220-90) in addition to 10 different isolates from 8 other antigenic groups. Control fish were injected with $50 \mu \mathrm{l}$ of immune serum or not injected and handled similarly but not exposed to virus.

Duplicate 25 -fish groups from each treatment were challenged with $10^{4}$ pfu $\mathrm{ml}^{-1}$ of IHNV by standard procedures (LaPatra et al. 1991a). Average cumulative percent mortality and mean number of days to death were calculated for each group. Cumulative percent mortality of the replicates was analyzed by analysis of variance on transformed (arcsin $\sqrt{\text { percentage) data }}$ (Snedecor \& Cochran 1967). Relative percent protection (RPP) for immune serum injected groups was calculated by the following formula:

RPP $=$

$\left[1-\frac{\text { (Cumulative } \% \text { mortality immune serum injected) }}{(\text { Cumulative } \% \text { mortality normal serum injected })}\right] \times 100$

Experimental groups were held in separate 19 l aquaria, monitored $28 \mathrm{~d}$ for mortality, and fed daily a dry pelleted diet (Clear Springs Foods, Inc., trout feed) ad libitum. At least $20 \%$ of the fish that died on any given day were tested for virus. Virus titers in whole fish or kidney-spleen-liver homogenates were determined for some fish examined in each test. Quantitation of virus used in fish exposures or isolated from dead fish was performed by plaque assay procedures previously described (LaPatra et al. 1989).

\section{RESULTS}

\section{Alpha neutralization tests}

Ten antigenic groups were identified based upon different neutralization profiles among the 106 isolates of IHNV that were reacted with 2 monoclonal antibod-
Table 1 Ten different neutralization profiles using monoclonal (1H8 and RB/B5) antibodies and polyclonal $(G$ and IHNV) antisera reacted with isolates of IHNV. Neutralization reactions were considered as positive $(+)$ if $>1.7 \log _{10}$ reduction in virus concentration was detected in plaque reduction assays. A negative $(-)$ in the table indicates neutralization $<1.7 \log _{110}$

\begin{tabular}{|cccccc|}
\hline $\begin{array}{l}\text { Antigenic } \\
\text { group }\end{array}$ & $\begin{array}{c}\text { Representative } \\
\text { Isolate }\end{array}$ & 1H8 & RBB5 & G & IHNV \\
\hline I & $039-82$ & + & - & + & + \\
II & $220-90$ & - & - & + & + \\
III & HV-90 & + & - & - & + \\
IV & $382-90$ & + & - & - & - \\
V & $428-91$ & + & + & - & + \\
VI & $426-91$ & + & + & - & - \\
VII & $201-91$ & - & - & - & - \\
VIII & $030-92$ & - & - & - & + \\
IX & $267-90$ & - & - & + & - \\
X & $033-92$ & + & - & + & - \\
\hline
\end{tabular}

ies and 2 polyclonal antisera (Table 1). Approximately $91 \%(96 / 106)$ of the antigenic variants were included within Groups II (42\%), III (12\%), and IV (37\%). While the isolates tested were obtained from acutely infected fish at 4 different geographic locations that ranged over 12 river miles, each location exhibited a different frequency of antigenic variants that included from 1 to 7 of the groups. Prevalence of isolates within a group from each location also varied widely (Table 2). Temporal variation in the frequency of different antigenic variant groups and in the prevalence of isolates within each group from 1990 to 1992 was also noted although no consistent pattern was observed (Table 3). Isolates that did not test positive in serum neutralization tests were confirmed to be IHNV by IFAT.

Table 2. Frequency of detection of different antigenic variants among IHNV isolates obtained at 4 different locations in the Snake River basin, Idaho, USA, from 1990 to 1992

\begin{tabular}{|c|c|c|c|c|c|c|}
\hline \multirow{2}{*}{$\begin{array}{c}\text { Antigenic } \\
\text { group }\end{array}$} & \multicolumn{5}{|c|}{ Frequency of occurrence } & \multirow{2}{*}{$\begin{array}{c}\text { Total } \\
\text { no. }\end{array}$} \\
\hline & $\begin{array}{l}\text { Location: } \\
\text { River mile: }\end{array}$ & $\begin{array}{c}A \\
600\end{array}$ & $\begin{array}{c}\text { B } \\
594\end{array}$ & $\begin{array}{c}C \\
593\end{array}$ & $\begin{array}{c}D \\
588\end{array}$ & \\
\hline I & & 0 & 0 & 0 & 2 & 2 \\
\hline II & & 19 & 8 & 11 & 5 & 43 \\
\hline III & & 0 & 8 & 2 & 4 & 14 \\
\hline IV & & 0 & 12 & 8 & 18 & 38 \\
\hline V & & 0 & 2 & 0 & 0 & 2 \\
\hline VI & & 0 & 0 & 1 & 0 & 1 \\
\hline VII & & 0 & 2 & 0 & 1 & 3 \\
\hline VIII & & 0 & 1 & 0 & 0 & 1 \\
\hline IX & & 0 & 1 & 0 & 0 & 1 \\
\hline$x$ & & 0 & 0 & 0 & 1 & 1 \\
\hline Subtotal: & & 19 & 34 & 22 & 31 & 106 \\
\hline
\end{tabular}


Table 3. Temporal variation of infectious hematopoietic necrosis virus isolates obtained at 4 locations $(A, B, C$ and $D)$ in the Snake River basin from 1990 to 1992

\begin{tabular}{|c|c|c|c|c|c|c|c|c|c|c|c|c|c|c|c|}
\hline \multirow{2}{*}{$\begin{array}{l}\text { Antigenic } \\
\text { group }\end{array}$} & \multicolumn{5}{|c|}{1990} & \multicolumn{5}{|c|}{1991} & \multicolumn{5}{|c|}{1992} \\
\hline & A & $B$ & C & D & Total $(\%)$ & A & B & C & $\mathrm{D}$ & Total $(\%)$ & A & $\mathrm{B}$ & C & $\mathrm{D}$ & Total $(\%)$ \\
\hline I & & & & & & & & & 2 & $2(4)$ & & & & & \\
\hline II & 5 & 3 & 7 & & $15(60)$ & 5 & 5 & 4 & 3 & $17(34)$ & 9 & & & 2 & $11(35)$ \\
\hline III & & 1 & & 2 & $3(12)$ & & 5 & 2 & 2 & $9(18)$ & & 2 & & & $2(7)$ \\
\hline IV & & 5 & & 1 & $6(24)$ & & 6 & 6 & 4 & $16(32)$ & & 1 & 2 & 13 & $16(52)$ \\
\hline $\mathrm{V}$ & & & & & & & 2 & & & $2(4)$ & & & & & \\
\hline VI & & & & & & & & 1 & & $1(2)$ & & & & & \\
\hline VII & & & & & & & 2 & & 1 & $3(6)$ & & & & & \\
\hline VIII & & & & & & & & & & & & 1 & & & $1(3)$ \\
\hline IX & & 1 & & & $1(4)$ & & & & & & & & & & \\
\hline$x$ & & & & & & & & & & & & & & 1 & $1(3)$ \\
\hline Totals & & & & & 25 & & & & & 50 & & & & & $31=106$ \\
\hline
\end{tabular}

\section{Virus challenge and passive immunization of fish}

Virulence comparisons using representative isolates of IHNV from Antigenic Groups I to VII to challenge rainbow trout of 2 different mean body weights resulted in average cumulative mortalities that ranged from 14 to $92 \%$. Based on cumulative percent mortality and mean number of days to death the isolate representing Antigenic Group I (039-82) appeared to be the least virulent and the isolate representing Group III (HV-90) was generally the most virulent regardless of fish size. Isolates representing Antigenic Groups II and IV to VII appeared to be of intermediate virulence (Table 4). Statistical analysis showed isolate 039-82 was significantly less $(p<0.05)$ virulent in both tests in agreement with previous reports that tested IHNV from this area (LaPatra et al. 1991a). Virus was isolated from $90 \%(196 / 217)$ of the dead fish examined and virus concentrations ranged from $10^{20}$ to $10^{73}$ with a mean of $10^{6.1} \mathrm{pfu}^{-1}$ of tissue. Dead fish examined after exposure to isolate 039-82 representing Antigenic Group I had the lowest prevalence ( $76 \%$ or $13 / 17$ ) and lowest concentration $\left(10^{4.1} \mathrm{pfu} \mathrm{g}^{-1}\right)$ of virus detected. Fish that died after exposure to isolate HV-90 (Antigenic Group III) had the highest prevalence $(94 \%$ or $34 / 36)$ and concentration $\left(10^{6.4}\right.$ pfu $\left.\mathrm{g}^{-1}\right)$ of IHNV.

Passive immunization of rainbow trout (mean weight $2.9 \mathrm{~g})$ with convalescent (immune) serum obtained from fish after waterborne exposure to IHNV isolate 220-90 (Antigenic Group II) provided protection after challenge with representative isolates from Groups III to $\mathrm{X}$. Fish that were injected with normal or naive fish serum averaged cumulative mortalities ranging from 16 to $54 \%$ (8/50 to $27 / 50$ ). Fish that received immune serum had mortalities ranging from 0 to $6 \%(0 / 50$ to $3 / 50)$. Virus was isolated from $88 \%(65 / 74)$ of the dead fish examined and virus concentrations ranged from $10^{2.5}$ to $10^{7.1}$ with a mean of $10^{5.6} \mathrm{pfu}^{-1}$ of tissue. Relative protection of immune serum compared to normal serum injected fish ranged from 92 to $100 \%$.

The experiment was repeated and fish (mean weight $1 \mathrm{~g})$ were immunized with either the same pool of convalescent serum produced against isolate $220-90$ or

Table 4. Oncorhynchus mykiss. Cumulative percent mortality (CPM) and mean number of days to death (MDD) of rainbow trout infected at 2 mean weights $(1.2$ and $4.8 \mathrm{~g})$ with representative isolates from Antigenic Groups I to VII. NM: no mortality

\begin{tabular}{|c|c|c|c|c|c|}
\hline \multirow{2}{*}{$\begin{array}{c}\text { Antigenic } \\
\text { group }\end{array}$} & \multirow{2}{*}{$\begin{array}{l}\text { IHNV } \\
\text { isolate }\end{array}$} & \multicolumn{2}{|c|}{$1.2 \mathrm{~g}$} & \multicolumn{2}{|c|}{$4.8 \mathrm{~g}$} \\
\hline & & CPM & MDD & CPM & MDD \\
\hline I & 039-82 & $\begin{array}{c}24 \\
(11 / 45)\end{array}$ & 14.6 & $\begin{array}{c}14 \\
(7 / 50)\end{array}$ & 11.1 \\
\hline II & $220-90$ & $\begin{array}{c}64 \\
(32 / 50)\end{array}$ & 10.4 & $\begin{array}{c}57 \\
(28 / 49)\end{array}$ & 10.0 \\
\hline III & HV-90 & $\begin{array}{c}88 \\
(43 / 49)\end{array}$ & 8.7 & $\begin{array}{c}92 \\
(44 / 48)\end{array}$ & 8.0 \\
\hline IV & $382-90$ & $\begin{array}{c}62 \\
(29 / 47)\end{array}$ & 11.9 & $\begin{array}{c}46 \\
(23 / 50)\end{array}$ & 8.7 \\
\hline V & $428-91$ & $\begin{array}{c}86 \\
(43 / 50)\end{array}$ & 9.4 & $\begin{array}{c}67 \\
(32 / 48)\end{array}$ & 7.8 \\
\hline VI & $426-91$ & $\begin{array}{c}91 \\
(42 / 46)\end{array}$ & 7.4 & $\begin{array}{c}60 \\
(27 / 45)\end{array}$ & 7.6 \\
\hline VII & $005-91$ & $\begin{array}{c}84 \\
(41 / 49)\end{array}$ & 8.0 & $\begin{array}{c}65 \\
(30 / 46)\end{array}$ & 7.6 \\
\hline Control & & $\begin{array}{c}4 \\
(1 / 24)\end{array}$ & 15.0 & $\begin{array}{c}0 \\
(0 / 25)\end{array}$ & NM \\
\hline
\end{tabular}


Table 5. Oncorhynchus mykiss. Passive immunization of rainbow trout with fish immune serum produced against isolate 220-90 of Antigenic Group II or normal fish serum (titer $<20$ ). Fish were given antiserum (titer 640 ) $24 \mathrm{~h}$ before virus challenge with $10^{4} \mathrm{pfu} \mathrm{ml^{-1 }}$ of the respective isolate. CPM: cumulative percent mortality; $\mathrm{MDD}$ : mean number of days to death, RPP: relative percent protection. NM: no mortality

\begin{tabular}{|c|c|c|c|c|c|c|}
\hline \multirow{2}{*}{$\begin{array}{l}\text { Antigenic } \\
\text { group }\end{array}$} & \multirow{2}{*}{$\begin{array}{l}\text { IHNV } \\
\text { isolate }\end{array}$} & \multicolumn{2}{|c|}{ Immune } & \multicolumn{2}{|c|}{ Normal } & \multirow[t]{2}{*}{ RPP } \\
\hline & & CPM & MDD & CPM & MDD & \\
\hline II & $220-90$ & $\begin{array}{c}0 \\
(0 / 49)\end{array}$ & NM & $\begin{array}{c}58 \\
(26 / 45)\end{array}$ & 10 & 100 \\
\hline III & HV -90 & $\begin{array}{c}0 \\
(0 / 50)\end{array}$ & NM & $\begin{array}{c}92 \\
(46 / 50)\end{array}$ & 8 & 100 \\
\hline IV & $382-90$ & $\begin{array}{c}0 \\
(0 / 44)\end{array}$ & NM & $\begin{array}{c}56 \\
(29 / 52)\end{array}$ & 9 & 100 \\
\hline v & $428-91$ & $\begin{array}{c}4 \\
(2 / 48)\end{array}$ & 12 & $\begin{array}{c}82 \\
(40 / 49)\end{array}$ & 8 & 91 \\
\hline VI & $426-91$ & $\begin{array}{c}4 \\
(2 / 51)\end{array}$ & 7 & $\begin{array}{c}82 \\
(40 / 49)\end{array}$ & 9 & 95 \\
\hline VII & $005-91$ & $\begin{array}{c}2 \\
(1 / 50)\end{array}$ & 17 & $\begin{array}{c}82 \\
(41 / 50)\end{array}$ & 9 & 98 \\
\hline VII & $292-91$ & $\begin{array}{c}0 \\
(0 / 49)\end{array}$ & NM & $\begin{array}{c}31 \\
(15 / 49)\end{array}$ & 10 & 100 \\
\hline VII & 201-91 & $\begin{array}{c}2 \\
(1 / 52)\end{array}$ & 12 & $\begin{array}{c}63 \\
(31 / 49)\end{array}$ & 10 & 97 \\
\hline VIII & $030-92$ & $\begin{array}{c}6 \\
(3 / 47)\end{array}$ & 11 & $\begin{array}{c}78 \\
(40 / 51)\end{array}$ & 8 & 89 \\
\hline IX & $267-90$ & $\begin{array}{c}0 \\
(0 / 50)\end{array}$ & NM & $\begin{array}{c}72 \\
(36 / 50)\end{array}$ & 9 & 100 \\
\hline$x$ & 033-92 & $\begin{array}{c}4 \\
(1 / 50)\end{array}$ & 7 & $\begin{array}{c}76 \\
(37 / 49)\end{array}$ & 9 & 97 \\
\hline Control & & $\begin{array}{c}0 \\
(0 / 25)\end{array}$ & NM & $\begin{array}{c}0 \\
(0 / 24)\end{array}$ & NM & \\
\hline
\end{tabular}

with normal serum. Similar results were obtained in this second test when injected fish were challenged with isolates representing Antigenic Groups II to X, including 3 isolates from Group VII containing variants that did not react with any of the serological reagents tested (Table 5). Cumulative percent mortality of all passively immunized fish was significantly less ( $p<$ 0.05) than fish injected with normal serum for each antigenic variant tested. There were no significant mortality differences between immune serum injected groups challenged with representative isolates from each antigenic group indicating significant crossprotection had occurred. Virus was detected in $93 \%$ (186/201) of the dead fish examined and IHNV concentrations ranged from $10^{34}$ to $>10^{73}$ with a mean of $10^{6.1} \mathrm{pfu}^{-1}$. The results substantiate significant crossprotection among isolates with diverse antigenic neutralizing epitopes.

\section{DISCUSSION}

The antigenic relationship among different IHNV isolates was first studied by McCain et al. (1971) who used a cross-neutralization assay with polyclonal antisera to show that strain variation existed. Later studies by Winton et al. (1988) and Ristow \& Arnzen de Avila (1991) used neutralizing monoclonal antibodies that reacted specifically with the IHNV glycoprotein to confirm the existence of antigenic variants. Additionally, Engelking et al. (1991) used neutralizing polyclonal antisera to compare IHNV isolates representing each of 5 electrophoretic groups and concluded that antigenic differences observed between virus strains were sufficient to define antigenic variants but not the existence of multiple serotypes. Groberg et al. (1990) reported the isolation of an unusual strain of IHNV from rainbow trout in the Snake River basin that was not neutralized by a monospecific polyclonal antiserum made against purified G protein of IHNV. However, results of additional studies suggested this isolate was a serological variant of the original serotype of IHNV (Groberg \& Miller 1993). Nonetheless, concerns about the epizootiological significance of novel serological variants and their implications for vaccine development warranted systematic monitoring using a battery of neutralizing reagents. Preliminary studies were reported by LaPatra et al. (1991a) who found unexpected heterogeneity in serum neutralization profiles among 8 isolates from a limited geographic area in the Snake River basin. In the study reported herein, 106 IHNV isolates obtained at 4 locations in a 12 mile section of the Snake River from 1990 to 1992 were classified into 10 antigenic groups. This suggests that antigenic variation may be much greater than previously thought which may adversely affect the development of an efficacious vaccine.

To minimize experimental variation, cross-neutralization assays were standardized and the results were not tabulated unless predicted reactions in control groups were observed. Reproducibility with these controls was, and continues to be, highly consistent. We have also tested representative variants after 1 pass through fish with good reproducibility (data not shown). The stability of these antigenic variants of IHNV is similar to that reported for other rhabdoviruses, Jørgensen (1972) examined 76 isolates of viral hemorrhagic septicemia virus (VHSV) by neutralization and found 2 serotypes which were stable after passage through fish and recloning. Smith (1988) examined 328 rabies virus isolates by immunofluorescence using monoclonal antisera against the viral $N$ protein and found 5 antigenically distinct reaction groups. The patterns observed for 2 of these groups were stable when the viruses were passed in vitro using a variety 
of animal cell cultures or in laboratory animals. Ristow \& Arnzen de Avila (1991) also reported variation in the reactivity of monoclonal antisera to the $N$ protein of several isolates of IHNV and presumably these variants would also be stable.

Comparison of geographic differences indicated that the upstream site (location A) yielded isolates that fell into only 1 antigenic group but multiple groups were detected at the other locations each year. No consistent annual variation was observed at each location over the 3 yr of the study. While the upstream site exhibited annual constancy, the other locations appeared to exhibit diversity that may have been somewhat dependent on the number of isolates that were examined. In 1992, fewer antigenic variant groups were detected throughout the area but the number of isolates examined was less. Examination of the frequency of occurrence of the variants for the entire area by year (Table 3) suggested there was a shift in the predominant group from II to IV. From 1990 to 1992, the prevalence of Group II isolates decreased from $60 \%(15 / 25)$ to $35 \%(11 / 31)$ whereas the prevalence of Group IV isolates increased from $24 \%(6 / 25)$ to $52 \%(16 / 31)$. Group II variants were neutralized by both polyclonal antibodies (G and IHNV) but Group IV was only recognized by monoclonal antibody $1 \mathrm{H} 8$. This suggests that antigenic variants from other sources may have been introduced into the region or that significant antigenic changes may have occurred.

There appeared to be some correlation between serum neutralization profiles and virulence which is in agreement with earlier studies (LaPatra et al. 1991a). Isolate 039-82 (Group I) consistently exhibited low virulence in the 2 sizes of fish tested. Isolate HV-90 (Group III) was generally the most virulent whereas representative isolates from other antigenic groups were generally intermediate in virulence. Classifying variants by neutralization profiles that correlate with virulence would provide a management tool to predict losses when IHNV is detected. However, this assumes that an isolate of IHNV recovered from a group of fish is representative of the entire viral population. Limited studies to date support this (LaPatra et al. 1991a, Wirkkula et al. 1991). This also assumes that virulence is stable after limited numbers of passes in different cell lines and that standardized challenges provide consistent results as shown by LaPatra et al. (1991b) suggesting stability.

LaPatra et al. (1993) reported that rainbow trout antiserum produced against 1 isolate of IHNV was capable of neutralizing representative isolates from 3 antigenic groups in vitro and providing passive protection against heterologous variants in vivo. Results of the present study extend these previous observations and confirm the cross-protective effect using additional, diverse antigenic variants. The conclusion of the crossprotection studies is that a single vaccine efficacious against one antigenic variant may also be protective against others. Basurco et al. (1993) hyperimmunized rainbow trout by injection with representative strains from each of the 5 IHNV electropherotypes. No major serological differences were detected in a cross-neutralization assay suggesting that fish recognize certain dominant antigens associated with neutralization. They concluded that production of a vaccine based on a single type of IHNV has the potential to protect against other known electropherotypes. Engelking \& Leong (1989) also found that if the G protein was subjected to denaturation with heat, detergent and reducing agents, epitopes were preserved that elicited a neutralizing antibody response. These results suggest the existence of a conserved linear epitope that could be used as a candidate vaccine. The presence of 1 or more linear epitopes on the G protein of IHNV has also been determined using monoclonal antibodies by Xu et al. (1991) and Huang et al. (1994). It has been suggested that fish have a more restricted and primitive antibody response than do mammals (Du Pasquier 1982, Arkoosh \& Kaattari 1991, Mourich \& Leong 1991) and that pooling serum from several rainbow trout does not enhance protection in passive immunization tests (LaPatra et al. 1993). The restricted but protective humoral immune response of fish to a dominant conserved linear epitope on the IHNV G protein that may cross-protect against all strains of the virus will be important in the development of vaccines. These results also indicate that immunogenic regions recognized by the rainbow trout immune system may not be identical to regions recognized by the rabbit or mouse. Antigenic variation of IHNV determined by antibodies produced in mouse or rabbits should be interpreted cautiously in future studies.

Because IHNV is an RNA virus and RNA viral genomes are known to exhibit high mutation rates (Holland et al. 1982), it is possible that variant types of IHNV will evolve (Winton 1992). However, results of $\mathrm{T}_{1}$ fingerprinting of 26 IHNV isolates recovered from 4 salmonid species from different locations in western North America indicated less overall genetic diversity among isolates of IHNV compared to vesicular stomatitis virus or other RNA viruses known to exhibit antigenic variation. The maximum variation in the RNA sequence of the IHNV genome for the isolates studied was estimated to be $<5 \%$. Potential explanations for the relatively low extent of genetic variation exhibited by IHNV compared to mammalian rhabdoviruses included a lower optimal temperature and thus a slower replication rate, a relatively short duration of actively replicating virus in an infected population, a lower level of immune selection because salmonids 
have a less sophisticated immune system, and finally the potential presence of vector(s) and/or reservoirs of IHNV that maintain and transmit isolates over time but place additional constraints upon variation (Oshima 1991).

In the future it will be important to determine the nucleotide sequence of the gene coding for the $G$ protein of the antigenic variants and to determine conserved immunogenic regions that could be targeted as candidate vaccines. It will also be important to identify potential mutations that may produce major antigenic changes and to determine the ability of the virus to develop mutations to escape protective effects of a vaccine. Additionally, antiserum produced in fish rather than the rabbit or mouse may be a more effective tool for determining immunogenic regions of a pathogen important for vaccine development.

Acknowledgements. The authors thank Jim Winton, National Fisheries Research Center, Seattle, Washington, USA, Mark Engelking, Oregon Department of Fish and Wildlife, Corvallis, Oregon, USA, and Randy MacMillan, Clear Springs Foods, for their critical review of the manuscript, Scott Williams for statistical analyses and Elaine Thompson for the editorial assistance (both from Clear Springs).

\section{LITERATURE CITED}

Amend, D. F, Chambers, V. C. (1970). Morphology of certain viruses of salmonid fishes. I. In vitro studies of some viruses causing hematopoietic necrosis. J. Fish. Res. Bd Can. 27: 1285-1293

Amend, D. F., Yasutake, W. T., Mead, R. W. (1969). A hematopoietic virus disease of rainbow trout and sockeye salmon. Trans. Am. Fish. Soc. 98: 796-804

Amos, K. H. (1985). Procedures for the detection and identification of certain fish pathogens, 3rd edn. Fish Health Section, American Fisheries Society, Corvallis, p. 6-21

Arkoosh, M. R., Kaattari, S. L. (1991). Development of immunological memory in rainbow trout (Oncorhynchus mykiss). I. An immunochemical and cellular analysis of the B cell response. Dev. comp. Immunol. 15: 279-293

Basurco, B., Yun, S., Hedrick, R. P. (1993). Comparison of selected strains of infectious hematopoietic necrosis virus (IHNV) using neutralizing trout antisera. Dis. aquat. Org. 15: $229-233$

Du Pasquier, L. (1982). Antibody diversity in lower vertebrates, why is it so restricted? Nature 296: 311-313

Engelking, H. M., Harry, J. B., Leong, J. L. (1991). Comparison of representative strains of infectious hematopoietic necrosis virus by serological neutralization and cross-protection assays. A.ppl. environ. Microbiol. 57: 1372-1378

Engelking, H. M., Leong, J. C. (1989). The glycoprotein of infectious hematopoietic necrosis virus elicits neutralizing antibody and protective response. Virus Res. 13: 213-230

Fijan, N., Sulimanovic, D., Bearzotti, M., Muzinic, D., Zwillenberg, L. D., Chilmonczyk, S., Vautherot, J. F., de Kinkelin, P. (1983). Some properties of the Epithelioma papulosum cyprini (EPC) cell line from carp Cyprinus carpio. Ann Virol. (Inst. Pasteur) 134E: 207-220

Groberg, W. J., Ediger, V. L., LaPatra, S. E. (1990). A unique serotype of infectious hematopoietic necrosis virus from
Hagerman Valley of Idaho. In: Proceedings of the Annual Northwest Fish Culture Conference. Idaho Department of Fish and Game, Boise, p. 69-76

Groberg, W. J., Fryer, J L. (1983). Increased occurrences of infectious hematopoietic necrosis virus in fish at Columbia Ruver basin hatcheries: 1980-1982. Publication of the Sea Crant College Program, Oregon State University, Corvallis, Oregon. Technical Paper No. 6620

Groberg, W J., Miller, E. (1993). Unique serovars of infectious hematopoletic necrosis virus from rambow trout at a commercial hatchery in Idaho. East. Oreg. Sci. J. 9: 1-8

Holland, J., Spindler, K., Horodyski, F., Grabau, E., Nichol, S. VandePol, S. (1982). Rapld evolution of RNA genomes. Science 215: 1577-1585

Hsu, Y. L., Engelking, H. M., Leong, J. C. (1986). Occurrence of different types of infectious hematopoietic necrosis virus in fish. Appl. environ. Microbiol. 52: 1353-1361

Huang, C. Chien, M.-S., Landolt, M., Winton, J. (1994). Characterization of the infectious hematopoietic necrosis virus glycoprotein using neutralizing monoclonal antibodies Dis. aquat. Org. 18: 29-35

Jørgensen, P. E. V. (1972). Egtved virus: antigenic variation in 76 virus isolates examined in neutralization tests and by means of the fluorescent antibody technique. Symp. Zool. Soc. Lond. 30: $333-340$

LaPatra, S. E., Lauda, K. A., Jones, G. R., Walker, S. (1991 b). Standardization of infectious hematopoietic necrosis virus challenge procedures. Am. Fish. Soc. Fish Health Section Newsletter 19(4): 3-5

LaPatra, S. E., Lauda, K. A., Morton, A. W. (1991a). Antigenic and virulence comparison of eight isolates of infectious hematopoietic necrosis virus from the Hagerman Valley, Idaho, USA. In: Proceedings of the Second International Symposium on Viruses of Lower Vertebrates. Oregon State University Press, Corvallis, p. 125-132

LaPatra, S. E., Roberti, K. A., Rohovec, J. S., Fryer, J. L. (1989). Fluorescent antibody test for the rapid diagnosis of infectious hematopoietic necrosis. J. aquat. Anim. Health 1. 29-36

LaPatra, S. E., Turner, T., Lauda, K. A., Jones, G. R., Walker S. (1993). Characterization of the humoral response of rainbow trout to infectious hematopoietic necrosis. J. aquat. Anim. Health 5: 165-171

Leong, J. C., Hsu, Y. L., Engelking, H. M., Mulcahy, D. (1981). Strains of infectious hematopoietic necrosis (IHN) virus may be identified by structural protein differences. In: Anderson, D. P., Hennessen, W. (eds.) International Symposium on Fish Biologies: Serodiagnostics and Vaccines. Devel. Biol. Stan. 49: 43-55

McCain, B. B., Fryer, J. L., Pilcher, K. S. (1971). Antigenic relationships in a group of three viruses of salmonid fish by cross neutralization. Proc. Soc. exp. Biol. Med. 137 1042-1046

Mourich, D. V., Leong, J. C. (1991). Mapping of the immunogenic regions of the IHNV glycoprotein in rainbow trout and mice. In: Proceedings of the Second International Symposium on Viruses of Lower Vertebrates. Oregon State University Press, Corvallis, p. 93-100

Oshima, K. H. (1991). Genetic diversity and epizootiology of infectious hematopoietic necrosis virus. Doctoral thesis, University of Washington, Seattle

Ristow, S. S., Arnzen, J. M. (1989). Development of monoclonal antibodies that recognize a Type 2 specific and common epitope on the nucleoprotein of infectious hematopoietic necrosis virus. J. aquat. Anim. Health 1: $119-125$

Ristow, S. S., Arnzen de Avila, J. (1991). Monoclonal antibod- 
ies to the glycoprotein and nucleoprotein of infectious hematopoietic necrosis virus (IHNV) reveal differences among isolates of the virus by fluorescence, neutralization, and electrophoresis. Dis aquat. Org. 11: 105-115

Rovozzo, G. C., Burke, C. N. (1973). Basic virological techniques. Prentice-Hall, Englewood Cliffs, NJ

Rucker, R. R., Whipple, W. J., Parvin, J. R., Evans, C. A. (1953). A contagious disease of salmon possibly of virus origin. U.S. Fish Wildlife Serv. Fish. Bull. 54: 35-46

Smith, J. S. (1988). Monoclonal antibody studies of rabies in insectivorous bats of the United States. Rev. infect. Dis. 10 $637-643$

Snedecor, G. W., Cochran, W. G. (1967). Statistical methods, 6th edn. Iowa State University Press, Ames

Williams, I., Amend, D. F. (1976). A natural epizootic of infectious hematopoietic necrosis in fry of sockeye salmon. Oncorhynchus nerka, at Chilko Lake, British Columbia. J. Fish. Res. Bd Can. 33: 1564-1567

Wingfield, W. H., Chan, L. D. (1970). Studies of the Sacramento River chinook disease and its causative agent. In: Snieszko, S. F. (ed.) A Symposium on Diseases of Fish and Shellfishes. American Fisheries Society Special Publica-

Responsible Subject Editor: F. M. Hetrick, College Park, Maryland, USA tion, Washington, DC, p. 307-318

Wingfield, W. H., Fryer, J. L., Pilcher, K. S. (1969). Properties of the sockeye salmon virus (Oregon strain). Proc. Soc. exp. Biol. Med. 130: 1055-1059

Winton, J. R. (1992). Evolution of fish rhabdoviruses. In: Proceedings of the OJI International Symposium on Salmonid Diseases. Hokkaido University Press, Sapporo, p. 88-95

Winton, J. R., Arakawa, C. K., Lannan, C. N., Fryer, J. L. (1988). Neutralizing monoclonal antibodies recognize antigenic variants among isolates of infectious hematopoietic necrosis virus. Dis. aquat. Org. 4: 199-204

Wirkkula, J. R., LaPatra, S. E., Rohovec, J. S., Fryer, J L. (1991). Intrarun virulence comparison of infectious hematopoietic necrosis virus from spawning salmonids. Am. Fish. Soc. Fish Health Section Newsletter 19(1): 3-4

Wolf, K. (1988). Fish viruses and fish viral diseases. Cornell University Press, Ithaca, p. 83-114

Xu, L., Mourich, D. V., Engelking, H. M., Ristow, S., Arnzen, J., Leong, J. C. (1991). Epitope mapping and characterization of the infectious hematopoietic necrosis virus glycoprotein, using fusion proteins synthesized in Escherichia coli. J. Virol. 65: 1611-1615

Manuscript first received: March 21, 1994

Revised version accepted: July 3, 1994 